\title{
Cellular Physiology

\section{Protective Role of Glucagon-like Peptide-1 Against Glucosamine-induced Cytotoxicity in Pancreatic Beta Cells}

\author{
Yu-Kyung Kim ${ }^{1}$, Jae-Hyung Park ${ }^{1}$, Sung-Hee Park ${ }^{1}$, Bora Lim ${ }^{1}$, Won- \\ Ki Baek ${ }^{2}$, Sung-Il Suh², Jung-Geun Lim¹, Gyeong Ryul Ryu ${ }^{3}$ and \\ Dae-Kyu Song ${ }^{1}$
}

${ }^{1}$ Department of Physiology \& Chronic Disease Research Center, ${ }^{2}$ Department of Microbiology, Keimyung University School of Medicine, Daegu, ${ }^{3}$ Department of Internal Medicine, The Catholic University of Korea, Seoul

\section{Key Words}

Glucosamine toxicity $•$ Glucagon-like peptide $1 \cdot$ AMPactivated protein kinase $\cdot$ Glucose uptake $\cdot$ Pancreatic beta cell

\section{Abstract}

High doses of glucosamine have been known to induce apoptosis of pancreatic beta cells. The mechanism for this phenomenon has not been clearly elucidated. We aimed to explore the potential mechanisms for glucosamine toxicity in the rat insulinoma cell line INS-1 and in rat native beta cells. We also investigated whether glucagon-like peptide (GLP)-1 could be protective against glucosamine. Glucosamine exhibited dose-dependent inhibition of cell survival and an increase in the cell population at the sub-G1 phase. Glucosamine was revealed to inhibit cellular glucose uptake, resulting in the activation of AMP-activated protein kinase (AMPK). Accordingly, phosphorylation of P70S6K and ribosomal protein S6 (S6RP) was decreased. Protein glycosylation appeared not to be involved in this cytotoxicity. Pretreatment with GLP-1 alleviated glucosamine-mediated inhibition of glucose uptake and lessened AMPK activation, thus allowing recovery of the phosphorylation levels of P70S6K and S6RP.

\section{KARGER}

Fax +4161306 1234

E-Mail karger@karger.ch

www.karger.com
(C) 2010 S. Karger AG, Basel

$1015-8987 / 10 / 0253-0211 \$ 26.00 / 0$

Accessible online at:

www.karger.com/cpb
The effect of GLP-1 was blocked by the adenylyl cyclase inhibitor MDL12330A but not by the protein kinase $\mathrm{A}$ inhibitor H89. Taken together, these data demonstrate that glucosamine may inhibit beta-cell survival by diminishing cellular glucose uptake independent of glycosylation. This glucosamine toxicity can be blocked by GLP-1, which leads to recovery of the glucose uptake through a PKAindependent, cAMP-dependent mechanism.

Copyright (c) 2010 S. Karger AG, Basel

\section{Introduction}

Glucosamine has been widely used as a supportive therapy to alleviate symptoms of degenerative arthritis, since it is a substrate for proteoglycan formation in cartilage and exerts anti-inflammatory effects [1]. It also has been considered as a potential supportive agent against some cancers [2]. However, in vitro and in vivo studies have revealed that, at its pharmacological doses, glucosamine increases peripheral insulin resistance $[3,4]$ and decreases the function and survival of pancreatic beta cells $[5,6]$. This diabetogenic effect may be primarily due to hyperactivity of the hexosamine biosynthesis pathway (HBP), in which glucosamine is a precursor of $N$ acetylglucosamine (Glc-NAc) for the enzymatic and non-

Dae-Kyu Song

Dept Physiol \& Chr Dis Res Center, Keimyung University School of Medicine 194 Dongsan-Dong, Jung-Gu, Daegu 700-712 (Republic of Korea) Tel. +82-53-250-7490; Fax +82-53-252-1605

E-Mail dksong@kmu.ac.kr; or E-Maildksong@dsmc.or.kr 
enzymatic glycosylation of various proteins [7]. In skeletal muscle and adipocytes, certain $O$-glycosylated proteins were shown to decrease cellular glucose uptake, thereby leading to insulin resistance [8-10]. In beta cells, glucosamine-induced $N$-glycosylation of F1-F0-ATP synthase resulted in less glucose-dependent ATP production and insulin secretion [5]. However, several reports have suggested that there may be another mechanism of glucosamine besides protein glycosylation [11-13]. In support of this hypothesis, rare beta-cell apoptosis was shown to occur along with peripheral insulin resistance in 8-wk-old transgenic mice with overexpression of glucosamine:fructose-6-phosphate amidotransferase (GFAT), which is the rate-limiting enzyme of HBP [14]. An investigation [15] also showed that, despite a significant increase in protein glycosylation levels, rat islet cell apoptosis or pathology was not observed $8 \mathrm{~h}$ after intravenous high glucose infusion, whereas it was observed after administration of glucosamine. Physiologically, high glucose levels in beta cells appeared to induce insulin hypersecretion without cellular apoptosis, at least in the early period of glucose exposure [16], suggesting that a much longer time may be needed for beta cells to develop glucotoxicity than glucosamine toxicity. Moreover, the types of glucose transporter (GLUT) should be considered in order to better understand differential mechanisms of glucosamine in beta cells. Glucosamine was shown to have greater affinity for GLUT2, which is responsible for glucose uptake of insulin-independent beta cells, than for other types of insulin-dependent GLUT [17]. These data raised the hypothesis that we have addressed in this study, which is that glucosamine toxicity in beta cells may be mainly due to a competition of glucosamine with glucose for entry into the cells, rather than a result of HBP-mediated protein glycosylation.

Glucagon-like peptide (GLP)-1, its analogues and DPP-IV inhibitors have received attention as new therapeutic drugs to manage type 2 diabetes. In beta cells, they enhance insulin gene expression and biosynthesis, glucose-dependent insulin secretion, and cell survival [18]. GLP-1 in beta cells acts through its G-protein-coupled receptors (GPCR), thereby activating adenylate cyclase and producing cAMP. Another beta-cell receptor transactivated via GLP-1 appears to be the epidermal growth factor receptor (EGFR), which activates the phosphoinositide (PI) 3-kinase pathway to promote cell growth and proliferation. In extrapancreatic tissues from normal dogs [19] and diabetic rodents [20-22], GLP-1 has been shown to increase cellular glucose uptake, probably via the mechanisms for recruiting PI3-kinase [23] and/or protein kinase B (Akt) [24]. However, there have been no studies with beta cells that have focused on whether GLP-1 can enhance glucose uptake, particularly in a situation in which glucose availability is compromised. Since the mechanism of glucose transportation into beta cells is different from that of glucose transportation into the cells of extrapancreatic tissues, the potentiating mechanism of GLP-1 could also be different. Hence, we have also evaluated whether GLP1 could protect against beta-cell glucosamine toxicity, which may interfere with cellular glucose uptake.

\section{Materials and Methods}

\section{Materials}

Glucosamine-hydrochloride (GlcN-HCl), glucagon-like peptide-1, 3-(4,5-dimethylthiazol-2-yl)-2,5-diphenyl tetrazolium bromide (MTT), methyl pyruvate, and tunicamycin (an inhibitor of $N$-glycosylation) were purchased from Sigma Chemical Co. (St. Louis, MO). The non-specific DPP IV inhibitor $(10 \mu \mathrm{M})$, which was purchased from Linco Research (St. Charles, MO), was co-treated with GLP-1. Benzyl-2-acetamido-2-deoxy-alphad-galactopyranoside (BADGP; an inhibitor of $O$-glycosylation) and O-(2-acetamido-2-deoxy-d-glucopyranosylidene) amino$\mathrm{N}$-phenylcarbamate (PUGNAc; an enhancer of $\mathrm{O}$-glycosylation) were purchased from Sigma and Carbogen (Bubendorf, Switzerland), respectively. Anti-Akt, anti-phospho-Akt, antiphospho-P70S6K, anti-phospho-S6RP, anti-acetyl-CoA carboxylase (anti-ACC), anti-phospho-ACC (Ser79), antiAMPK, anti-phospho-AMPK- $\alpha$ (Thr172), and LY294002 were purchased from Cell Signaling Technology (Beverly, MA). The anti-glycosylation antibody (CTD 110.6) was purchased from Abcam (Cambridge, MA). H-89 was purchased from Cayman Chemical (Ann Arbor, MI), and MDL 12330A (an adenylyl cyclase inhibitor) was purchased from RBI (Natick, MA).

\section{INS-1 cell and islet cell culture}

Rat insulinoma INS-1 cells were cultured in RPMI 1640 medium supplemented with $10 \%$ fetal bovine serum (FBS), 2 $\mathrm{mM}$ L-glutamine, $1 \mathrm{mM}$ sodium pyruvate, $50 \mu \mathrm{M} \beta$ mercaptoethanol, penicillin $(50 \mathrm{U} / \mathrm{ml})$ and streptomycin $(50 \mathrm{U} /$ $\mathrm{ml}$ ) in a humidified atmosphere with $5 \% \mathrm{CO}_{2}$ at $37^{\circ} \mathrm{C}$. Islets of Langerhans were isolated from the pancreas of male SpragueDawley rats using a collagenase digestion technique. The islets were placed into Krebs Ringer Bicarbonate (KRB) buffer solution containing $10 \% \mathrm{BSA}$, penicillin $(100 \mathrm{U} / \mathrm{ml})$ and streptomycin $(0.1 \mathrm{mg} / \mathrm{ml})$. To collect single islet cells, the islets were further triturated and incubated in RPMI-1640 media with $11.1 \mathrm{mM}$ glucose, $10 \%$ FBS and the antibiotics in a humidified incubator at $37^{\circ} \mathrm{C}$ with $5 \% \mathrm{CO}_{2}$ and balanced air. All procedures were approved by the Institutional Guideline Committee for Animal Experiments.

Kim/Park/Park/Lim/Baek/Suh/Lim/Ryu/Song 


\section{Adenoviral infection}

INS-1 cells were infected with an adenovirus expressing the wild type of AMPK- $\alpha$ (Ad-AMPK-WT) and the dominantnegative form of AMPK- $\alpha$ (D157A; Ad-AMPK-DN), which were generously provided by Dr. Joohun Ha, Kyung Hee University, Korea. Following $2 \mathrm{~h}$ incubation with the adenoviruses (multiplicity of infection 100), INS-1 cells in 24well culture plates at a density of $2 \times 10^{5}$ cells/well were incubated with fresh medium under normoxic conditions (95\% air, 5\% $\mathrm{CO} 2)$ at $37^{\circ} \mathrm{C}$ for $24 \mathrm{~h}$. Then, the cells were further treated with $7.5 \mathrm{mM}$ glucosamine for the indicated times.

Trypan blue assay and 3-(4,5-dimethylthiazol-2-yl)-2,5diphenyltetrazolium bromide (MTT) assay

INS-1 cell viability was measured by trypan blue and MTT assays. INS-1 cells were seeded in 96-well culture plates at a density of $6 \times 10^{5}$ cells/well. On the next day, the culture media was replaced with serum-free media and incubated for $24 \mathrm{~h}$. After serum starvation, the cells were treated as indicated in the figure legends and incubated for $48 \mathrm{~h}$. For the trypan blue assay, cells were trypsinized and suspended in growth media. Then the cells were mixed with the same volume of $0.4 \%$ trypan blue stain (Gibco, Carlsbad, CA) and counted on a hemocytometer. The percentage of viable cells [(total cellsdead cells)/ total cells] $\times 100$ was calculated. For the MTT assay, cells were labeled with MTT solution ( $2 \mathrm{mg} / \mathrm{ml}$ stock solution) for $4 \mathrm{~h}$ and the resulting formazan was solubilized with DMSO $(100 \mu 1)$. The absorption was measured at $570 \mathrm{~nm}(620 \mathrm{~nm}$ as a reference) using a Bio-Rad microplate reader (Hercules, CA).

Flow cytometry assessment of the cell cycle

For flow cytometric analysis of DNA content, approximately $6 \times 10^{5}$ INS-1 cells/well were fixed in $80 \%$ ethanol at $-20^{\circ} \mathrm{C}$. Ethanol-fixed cells were stained with a propidium iodide (PI) staining solution $(50 \mu \mathrm{g} / \mathrm{ml} \mathrm{PI} \mathrm{and} 100 \mu \mathrm{g} / \mathrm{ml}$ RNase A, $0.1 \%$ sodium citrate $(\mathrm{w} / \mathrm{v})$, and $0.1 \% \mathrm{NP}-40(\mathrm{v} / \mathrm{v}))$ for $30 \mathrm{~min}$. Cytometric analysis was performed with a flow cytometer (FACS Caliber, Becton Dickinson, San Jose, CA) and Cell Quest software.

\section{ATP measurement}

ATP was assayed by luciferase measurement (Invitrogen, Carlsbad, CA), according to the manufacturer's protocol. INS1 cells in 35-mm tissue culture dishes at a density of $6 \times 10^{5}$ cells/well were starved for $20 \mathrm{~min}$ in glucose-free KRB buffer. After without or with $100 \mathrm{nM} \mathrm{GLP}-1$ pretreatment for $20 \mathrm{~min}$, cells were exposed to $3 \mathrm{mM}$ or $20 \mathrm{mM}$ glucose for $10 \mathrm{~min}$ and then harvested.

Measurement of cellular 2-deoxy-[3H]-glucose uptake

INS-1 and beta cells cultured in $35-\mathrm{mm}$ tissue culture dishes at a density of $1 \times 10^{6}$ cells/well were washed with and incubated in $\mathrm{KRB}\left(136 \mathrm{mM} \mathrm{NaCl}, 4.7 \mathrm{mM} \mathrm{KCl}, 10 \mathrm{mM} \mathrm{NaPO}_{4}\right.$, $0.5 \mathrm{mM} \mathrm{MgCl}_{2}, 1 \mathrm{mM} \mathrm{CaCl}_{2}$ ) for $20 \mathrm{~min}$. After treatment of the cells as indicated in the figure legends, the cells were then incubated in $\mathrm{KRB}$ containing $0.5 \mu \mathrm{Ci} / \mathrm{ml}$ 2-deoxy- $\left[{ }^{3} \mathrm{H}\right]$-glucose (PerkinElmer Life and Analytical Science, Waltham, MA) for 10 min. The reaction was terminated by washing with ice-cold

Beta-Cell Glucosamine Toxicity and GLP-1 phosphate buffered saline (PBS). The cells were lysed in $1 \mathrm{~N}$ $\mathrm{NaOH}$, and the radiation was assessed by scintillation counting. The values were normalized according to the total amount of cellular protein and expressed as percentage of the control values.

\section{Western blotting}

INS-1 cells were seeded in $60 \mathrm{~mm}$-tissue culture dishes at a density of $6 \times 10^{5}$ cells/well and allowed to attach to the dishes for $24 \mathrm{~h}$. The cells were cultured in serum-free RPMI media for $24 \mathrm{~h}$. After treatment of the cells as indicated in the figure legends, the cells were maintained in culture for the indicated times. Then the cells were washed twice in ice-cold PBS and lysed in $50 \mu 1$ RIPA lysis buffer (20 mM Tris-HCl, 137 $\mathrm{mM} \mathrm{NaCl}, 10 \%$ glycerol, $1 \%$ Triton X-100, 2 mM EDTA, 1 mM PMSF). The protein concentrations were measured using the Bio-Rad protein assay (Hercules, CA). An equal amount of protein was electrophoresed on SDS-PAGE (10\%) gels and transferred to nitrocellulose membranes (Schleicher \& Schuell, Keene, NH). The membranes were blocked in Tris-buffered saline $-0.05 \%$ Triton X-100 (TBS-T) $-4 \%(\mathrm{w} / \mathrm{v})$ milk for $1 \mathrm{~h}$ at room temperature. The membranes were then incubated with primary antibodies diluted in TBS-T $-4 \%(\mathrm{w} / \mathrm{v})$ milk for $1 \mathrm{~h}$ at room temperature or overnight at $4{ }^{\circ} \mathrm{C}$ (in the case of phosphospecific antibodies). Subsequently, the membranes were washed with TBS-T and incubated with horseradish peroxidase secondary antibody (1:2,000; Amersham Biosciences, Fairfield, $\mathrm{CT})$ diluted in TBS-T $-4 \%(\mathrm{w} / \mathrm{v})$ milk. The membranes were washed in TBS-T, and bound antibody was detected by enhanced chemiluminescence (Amersham). The experiments were repeated at least three times, analyzed by NIH-Image software, and then normalized to the band density of the respective total protein when necessary.

\section{Statistical analysis}

The results are expressed as means \pm SEM. The SPSS (release 14.0) software package (SPSS Inc., Chicago, IL) was used for the statistical analyses. Comparisons between two groups were performed with the Student's two-tailed $t$-test for paired or unpaired data. For comparisons of more than two groups, significance was determined using ANOVA with Bonferroni correction. Differences between groups were considered significant when $\mathrm{p}<0.05$.

\section{Results}

\section{Effect of glucosamine on beta-cell survival}

INS-1 cells were incubated for $48 \mathrm{~h}$ in serum-free, $11.1 \mathrm{mM}$ glucose-containing media with various concentrations of glucosamine, and then cell survival was evaluated using cell counting and the MTT assay (Fig. $1 \mathrm{~A}$ and $\mathrm{B})$. The results showed that glucosamine dosedependently inhibited cell survival. At $7.5 \mathrm{mM}$ glucosamine, the inhibition was about $50 \%(\mathrm{p}<0.001)$. To evaluate the causes of glucosamine-induced 
Fig. 1. Effects of glucosamine $(\mathrm{GlcN})$ and PUGNAc on INS-1 cell survival. Cells were incubated in serum-free RPMI media for $24 \mathrm{~h}$ and then exposed to the chemicals at the indicated concentrations for $48 \mathrm{~h}$ in the serum-free media. Percent cell survival was determined using the trypan blue assay (panel A) and MTT assay (panel B and C). Cellular levels of protein glycosylation were detected by Western blot (panel D). Whole-cell lysates were prepared and analyzed by immunoblotting. The results are expressed as means \pm SEM, $n=3-7$ separate wells of cells in at least three separate experiments. ${ }^{*} \mathrm{p}$ $<0.05, * * \mathrm{p}<0.01, * * * \mathrm{p}<0.001$ compared with control values.

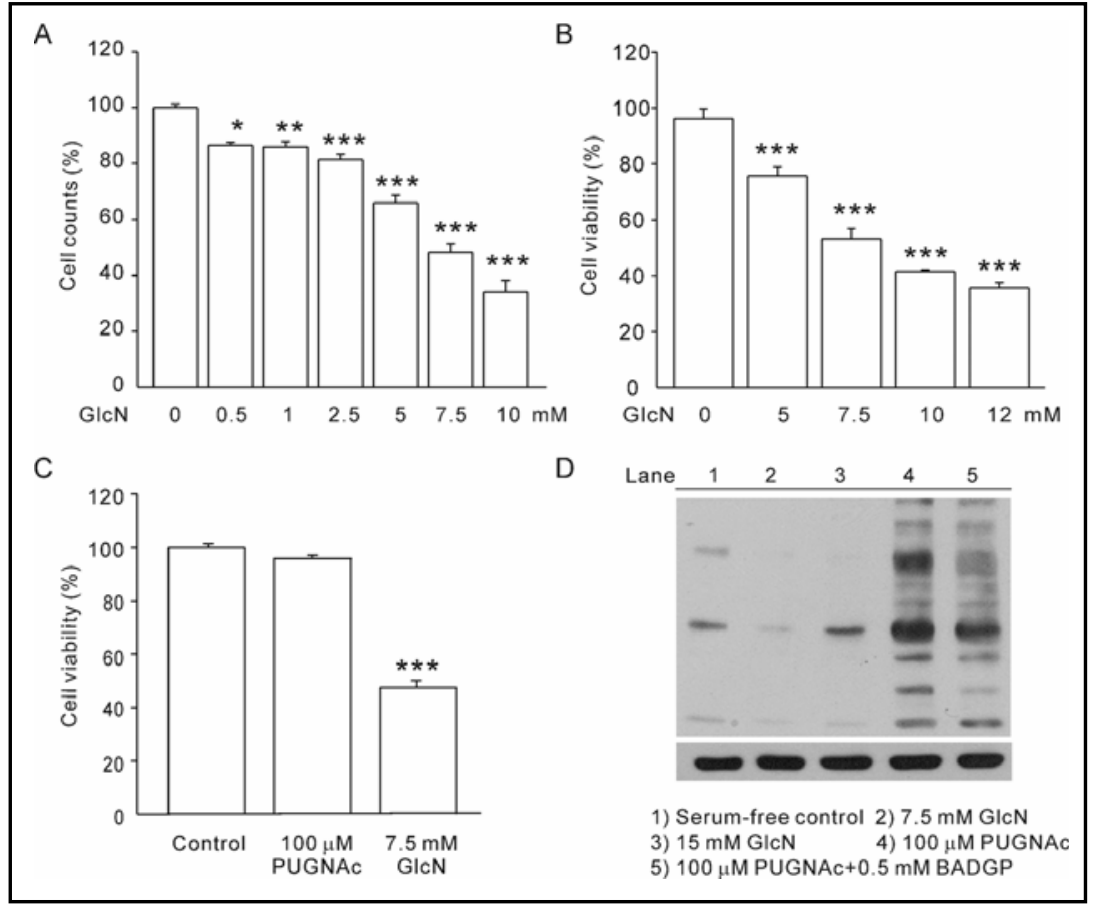

Fig. 2. Effects of glucosamine $(\mathrm{GlcN})$ and GLP-1 on cell cycle distribution in INS- 1 cells. Cells were incubated in serum-free RPMI media for $4 \mathrm{~h}$. After pretreatment with GLP1 at the indicated concentrations for $1 \mathrm{~h}$, cells were further treated with $7.5 \mathrm{mM}$ GlcN for $24 \mathrm{~h}$. The cell cycle distribution was determined by flow cytometric analysis of the DNA content after staining with propidium iodide as described in Materials and Methods. The drawing is representative, and the population at the sub-G1 phase is expressed as means \pm SEM, $n=3$ in at least three separate experiments.
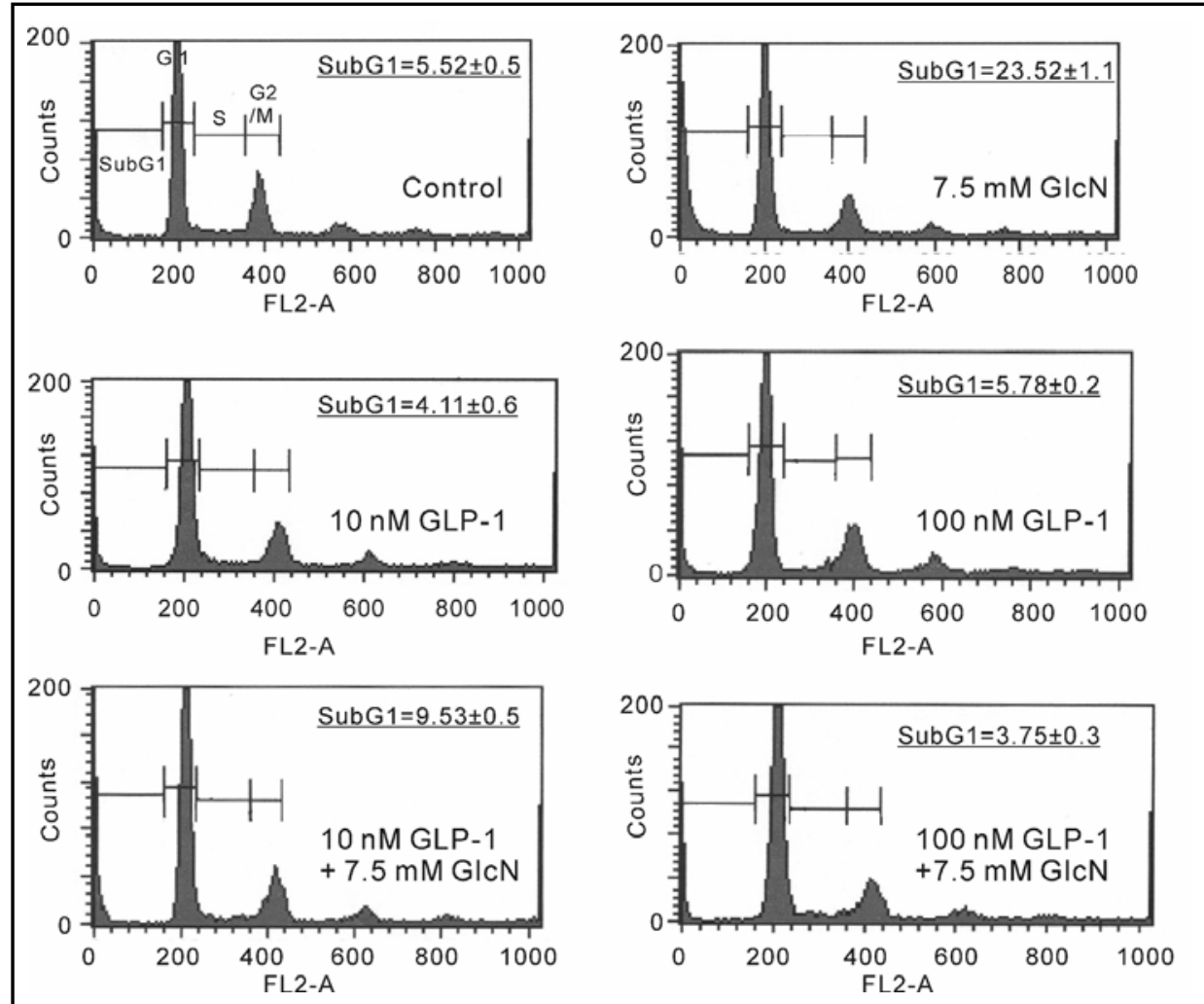

cytotoxicity, INS-1 cells were treated with $100 \mu \mathrm{M}$ PUGNAc alone, a protein glycosylation facilitator, for 48 h. As shown in Fig. 1C, no significant cell death was observed, although $7.5 \mathrm{mM}$ glucosamine significantly decreased cell viability. Interestingly, the extent of protein $O$-glycosylation was much more severe in the cells treated with PUGNAc than with glucosamine (Fig. 1D).
Effect of GLP-1 and methyl pyruvate on glucosamine-induced cell death

Exposure of INS-1 cells to $7.5 \mathrm{mM}$ glucosamine for $48 \mathrm{~h}$ resulted in an increased cell population at the subG1 phase of the cell cycle (Fig. 2). Pretreatment with GLP-1 (10 nM or $100 \mathrm{nM})$ significantly alleviated the effect of glucosamine. Consistently, when assessed by

Kim/Park/Park/Lim/Baek/Suh/Lim/Ryu/Song 


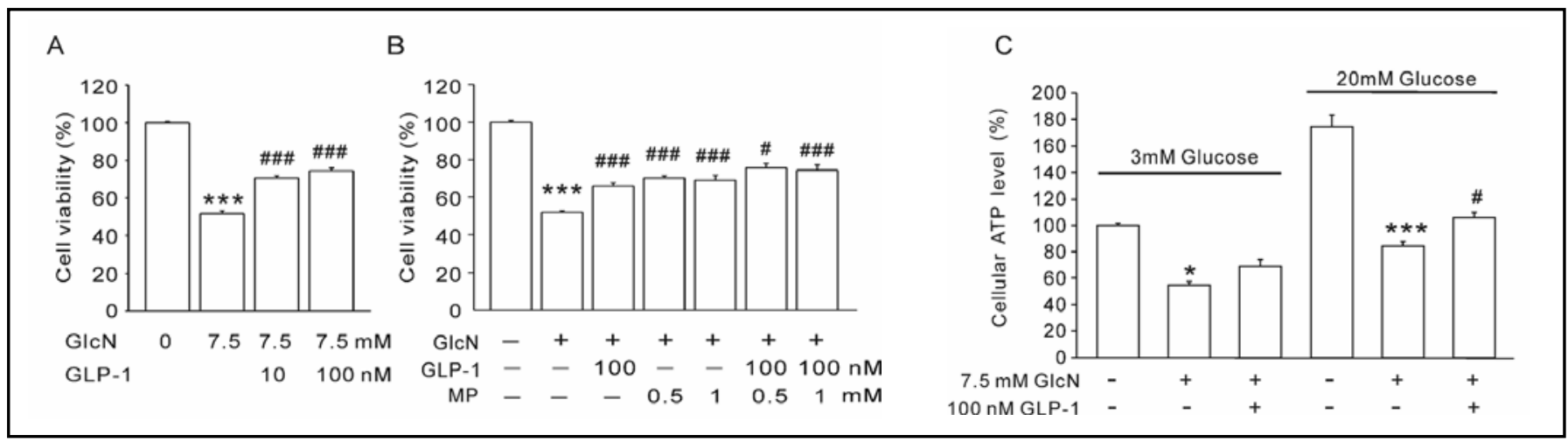

Fig. 3. Effects of GLP-1 on cell survival and cellular ATP levels against glucosamine (GlcN) toxicity in INS-1 cells. Cells were incubated in serum-free RPMI media for $24 \mathrm{~h}$. After pretreatment with GLP-1 (panel A) and/or methyl pyruvate (MP; panel B) at the indicated concentrations for $1 \mathrm{~h}$, cells were then treated with $7.5 \mathrm{mM} \mathrm{GlcN}$ for $48 \mathrm{~h}$. Percent cell survival was determined using the MTT assay. For measurement of cellular ATP levels (panel C), cells were preincubated in KRB buffer for 20 min and then incubated for an additional $20 \mathrm{~min}$ without or with $100 \mathrm{nM}$ GLP-1. Then, $3 \mathrm{mM}$ or $20 \mathrm{mM}$ glucose was added with or without GlcN, and maintained in culture for $10 \mathrm{~min}$. The results are expressed as means $\pm \mathrm{SEM}, \mathrm{n}=5-18$ separate wells of cells in at least three separate experiments. ${ }^{*} \mathrm{p}<0.05,{ }^{* * *} \mathrm{p}<0.001$ compared with control values without GlcN treatment; ${ }^{\#} \mathrm{p}<0.05,{ }^{\# \#} \mathrm{p}<0.001$ compared with the values for cells treated with GlcN alone.

Fig. 4. Effects of glucosamine $(\mathrm{GlcN})$ and GLP-1 on phosphorylation levels of cellular signaling proteins in INS-1 cells. Cells were incubated in serumfree RPMI media for 24 h. After a 1-h pretreatment with or without GLP-1, cells were further treated with GlcN for $48 \mathrm{~h}$ (panel A and B) or the indicated times (panel $\mathrm{C}$ and $\mathrm{D}$ ) in the serumfree media. The wholecell lysates were collected at the indicated times and analyzed by immunoblotting.

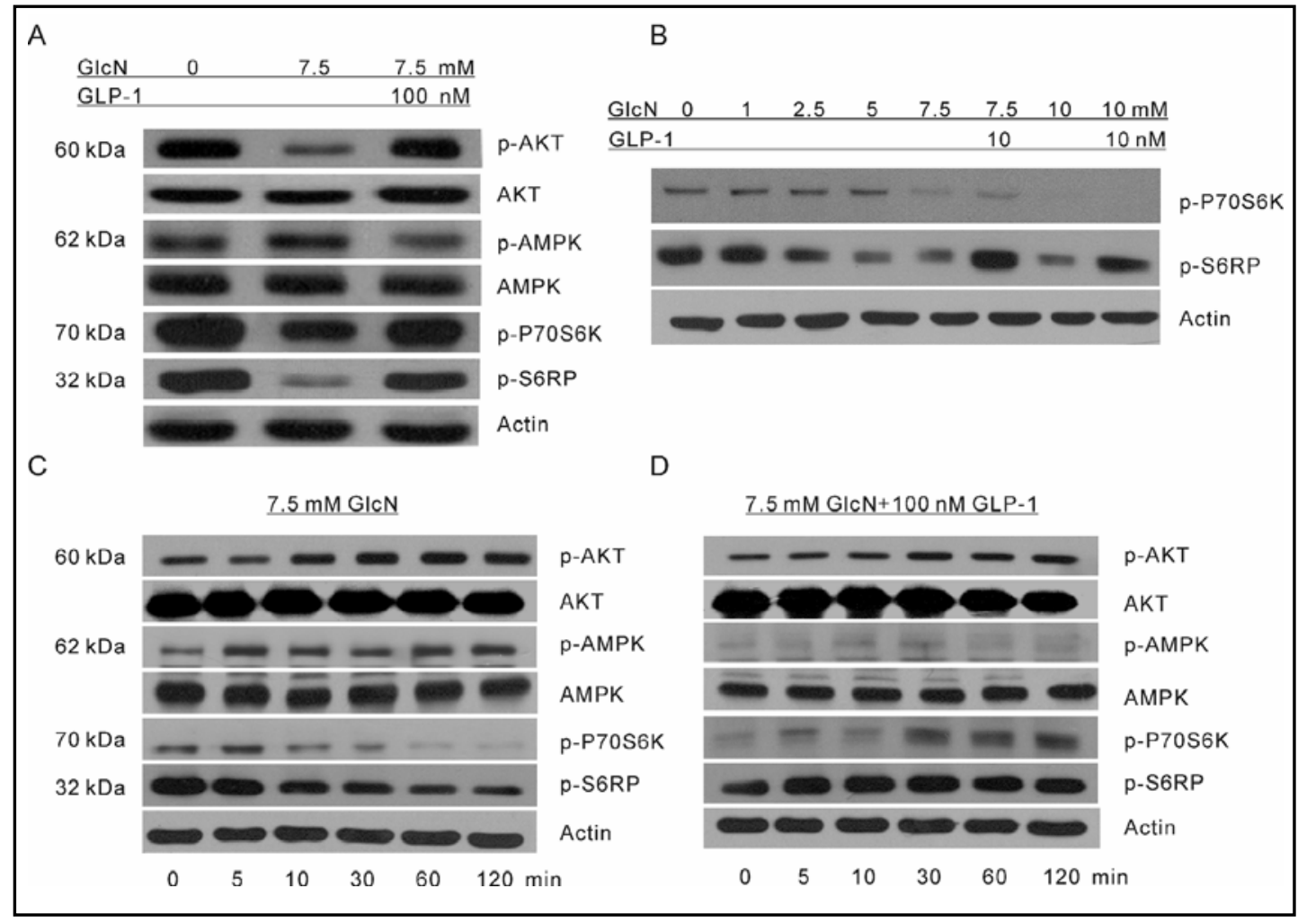

the MTT assay, GLP-1 led to recovery of cell viability following glucosamine treatment (Fig. 3A). As an alternative cellular energy entering the cells independently of GLUT2, methyl pyruvate was added to glucosaminecontaining media during a 48-h incubation period. As expected, glucosamine cytotoxicity was greatly ameliorated, to an extent that was comparable to the effect

Beta-Cell Glucosamine Toxicity and GLP-1 of GLP-1 (Fig. 3B). Hence, we measured cellular ATP levels in the presence of $3 \mathrm{mM}$ or $20 \mathrm{mM}$ glucose. Cellular ATP levels were significantly lower in glucosamine-treated cells than in control cells. Pretreatment with GLP-1 remarkably restored cellular ATP levels decreased by glucosamine, although they did not reach to the control ATP levels (Fig. 3C). 
Fig. 5. Effects of glucosamine (GlcN) on 2-deoxy$\left[{ }^{3} \mathrm{H}\right]$-glucose uptake in INS-1 cells. Cells were preincubated in KRB buffer for $20 \mathrm{~min}$ and then incubated for an additional $20 \mathrm{~min}$ without (panel A), or with BADGP (panel B) or tunicamycin (panel C). Then, 2-deoxy- $\left[{ }^{3} \mathrm{H}\right]$-glucose was added with or without GlcN, and maintained in culture for $10 \mathrm{~min}$. The results are expressed as means \pm SEM, $n=5-10$ separate wells of cells in at least three separate experiments. ${ }^{* * *} \mathrm{p}<0.001$ compared with control values.
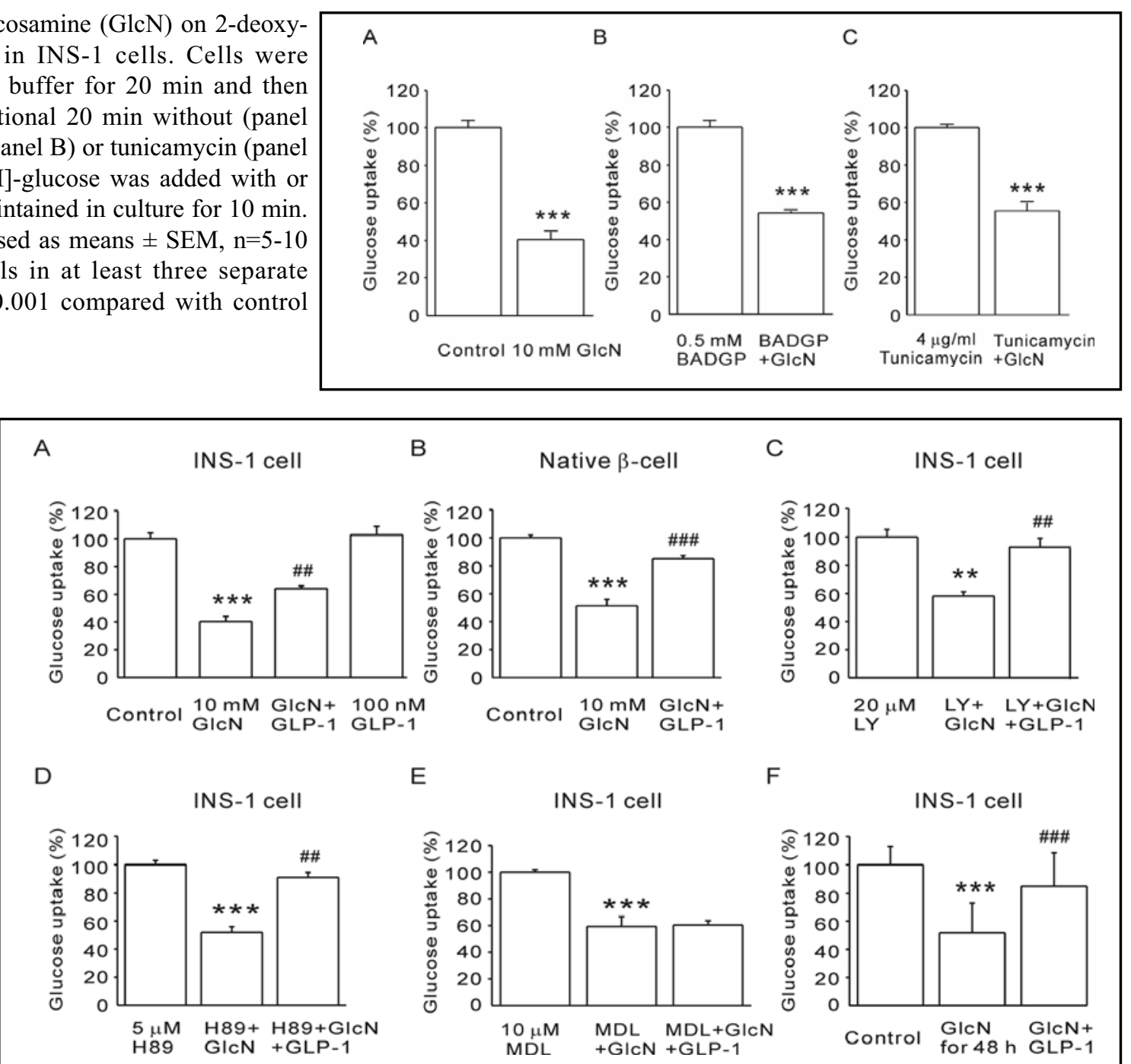

Fig. 6. Alleviating effect of GLP-1 on glucosamine-mediated decrease in 2-deoxy-[ $\mathrm{H}]$-glucose uptake in INS-1 and native rat beta cells. INS-1 and native beta cells were preincubated in KRB buffer for 20 min and then incubated for an additional $20 \mathrm{~min}$ with or without each indicated drug. Then, 2-deoxy-[$\left.{ }^{3} \mathrm{H}\right]$-glucose was added with or without GlcN, and maintained in culture for $10 \mathrm{~min}$. In panel F, cells were treated with GlcN for $48 \mathrm{~h}$ without or with GLP-1. The results are expressed as means \pm SEM, $\mathrm{n}=5-10$ separate wells of cells in at least three separate experiments. ${ }^{* *} \mathrm{p}<0.01,{ }^{* * *} \mathrm{p}<0.001$ compared with control values without GlcN treatment; ${ }^{\#} \mathrm{p}<0.01,{ }^{\# \#} \mathrm{p}<0.001$ compared with the values for cells treated with GlcN alone under the indicated conditions.

Effect of glucosamine and GLP-1 on phosphorylation of cellular signaling molecules

When INS-1 cells were treated with $7.5 \mathrm{mM}$ glucosamine for $48 \mathrm{~h}$, the phosphorylated forms of Akt (p-Akt), P70S6K (p-P70S6K) and S6RP (p-S6RP) were significantly decreased compared with those in the control cells without glucosamine (Fig. 4A and B). The phosphorylated form of AMPK (p-AMPK) was increased by the treatment with glucosamine, suggesting that the cells chronically have high AMP/ATP levels. GLP-1 led to recovery of the glucosamine-induced decrease in p-Akt, p-P70S6K and p-S6RP and increase in $\mathrm{p}$-AMPK. To elucidate the mechanism that is critical for glucosamine cytotoxicity in INS-1 cells, we observed time-dependent changes in the phosphorylation levels of cellular signaling molecules in the presence of $7.5 \mathrm{mM}$ glucosamine. When measured at $5 \mathrm{~min}$ after glucosamine exposure, the increased AMPK phosphorylation was evident (Fig. 4C), suggesting that cellular ATP levels decreased acutely. The levels of p-P70S6K and p-S6RP exhibited a time-dependent decrease. Interestingly, p-Akt levels were increased at this early time period, suggesting

Kim/Park/Park/Lim/Baek/Suh/Lim/Ryu/Song 
that Akt signaling is not preferentially involved in glucosamine-mediated inhibition of protein synthesis. Pretreatment with $100 \mathrm{nM}$ GLP-1 was able to block the early activation of AMPK (Fig. 4D). Glucosaminemediated inhibition of the phosphorylation of P70S6K and S6RP was also alleviated by GLP-1.

Effect of glycosylation inhibitors or GLP-1 against glucosamine blockade of glucose uptake in INS-1 and native beta cells

Next, the effect of glucosamine on glucose uptake of INS-1 cells was evaluated. Cellular uptake of glucose was inhibited by acute treatment with glucosamine (Fig. $5 \mathrm{~A})$. The inhibition was not blocked by a 20 -min pretreatment with the $O$-glycosylation inhibitor BADGE $(0.5 \mathrm{mM})$ or the $N$-glycosylation inhibitor tunicamycin (4 $\mu \mathrm{g} / \mathrm{ml}$ ) (Fig. 5B and C). However, pretreatment with 100 nM GLP-1 significantly ameliorated glucose uptake in INS-1 cells (Fig. 6A) and native beta cells (Fig. 6B) when compared to glucose uptake in cells treated with glucosamine alone. This effect of GLP-1 was observed even in the presence of LY294002 (Fig. 6C) or H-89 (Fig. 6D). In contrast, the adenylyl cyclase inhibitor MDL12330A significantly blocked the effect of GLP-1 (Fig. 6E), suggesting that GLP-1 may exert its effect through generation of cAMP. To confirm that cellular glucose uptake was also impaired $48 \mathrm{~h}$ after glucosamine treatment, glucose uptake was measured in INS-1 cells exposed to glucosamine for $48 \mathrm{~h}$. The glucose uptake was shown to be impaired to a similar extent and showed significant recovery after pretreatment with GLP-1 (Fig. $6 \mathrm{~F})$.

Effect of glucosamine on viability of cells genetically suppressing AMPK activity

Cell survival during inhibition of glucose uptake by glucosamine may require a metabolic readjustment against decrease in cellular ATP concentrations [25]. We hypothesized that AMPK would be activated in response to ATP depletion by glucosamine in order to reduce cellular energy consumption, which would often involve the deceleration of protein synthesis rate. To this end, we infected INS- 1 cells with an adenovirus either expressing the wild-type form of AMPK (Ad-AMPK-WT) or the dominant negative form of AMPK (Ad-AMPK-DN) (Fig. 7A), as described in the Materials and Methods. When cell viability was compared between the two groups after $7.5 \mathrm{mM}$ glucosamine treatment, time-dependent decrease in cell survival was greater in the Ad-AMPK-DN cells (Fig. 7B), indicating that AMPK is activated by

Beta-Cell Glucosamine Toxicity and GLP-1
A

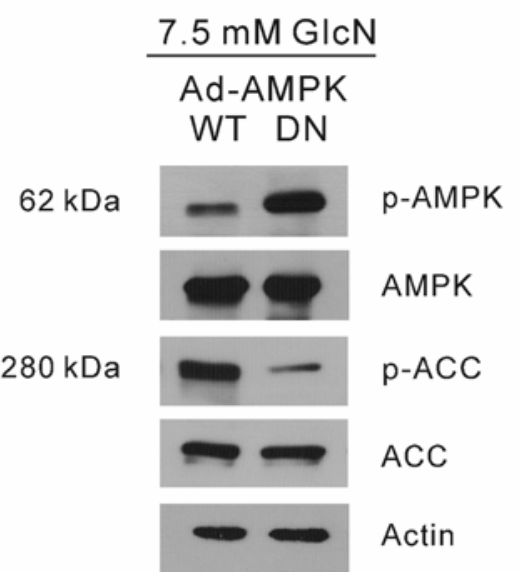

B

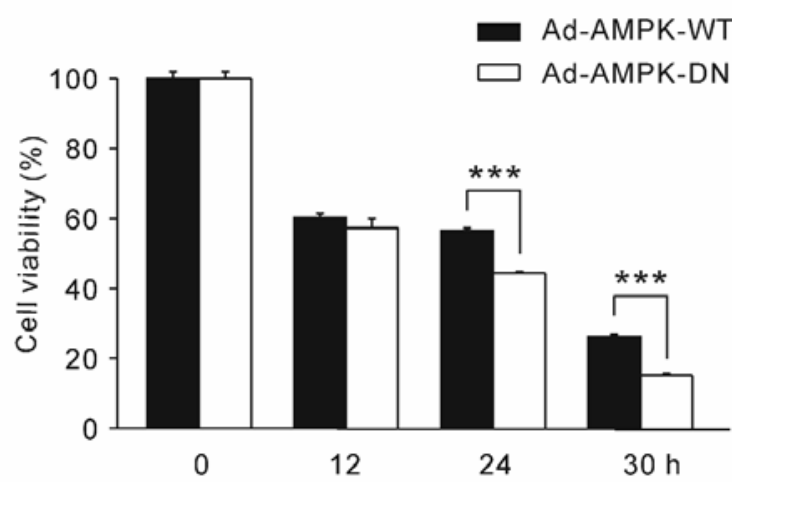

Fig. 7. Effect of glucosamine (GlcN) on viability of INS-1 cells possessing either adenovirally-mediated AMPK-wild type (AdAMPK-WT) or AMPK-dominant negative (Ad-AMPK-DN) form. Cells were infected with adenovirus for $2 \mathrm{~h}$, and then washed and incubated in serum-free RPMI media for $24 \mathrm{~h}$. Cells were further treated with $7.5 \mathrm{mM} \mathrm{GlcN}$ for $1 \mathrm{~h}$ (panel A) or the indicated times (panel B) in the serum-free media. The wholecell lysates were then collected and analyzed by immunoblotting (panel A). Percent cell survival was determined using the MTT assay (panel B). ${ }^{* * *} \mathrm{p}<0.001$ compared with the values of AdAMPK-WT obtained at the same time point.

glucosamine, which lowers cellular ATP levels, to rearrange cellular metabolism to match the reduced energy.

\section{Discussion}

The present findings suggest that glucosamine might persistently decrease cellular glucose uptake during an exposure period of $48 \mathrm{~h}$, thereby leading to beta-cell death 


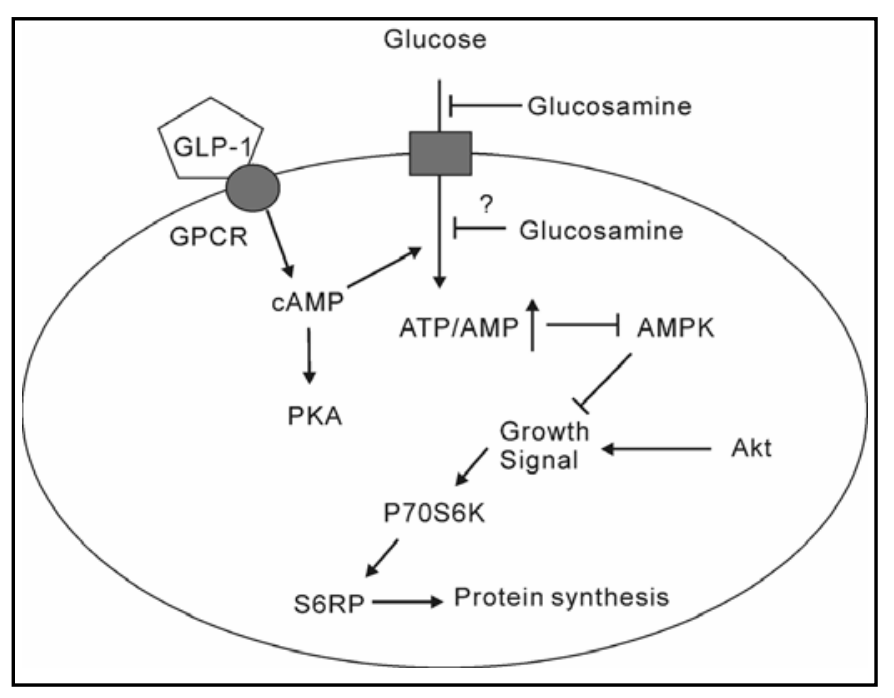

Fig. 8. Schematic representation of the effect of GLP-1 against glucosamine $(\mathrm{GlcN})$ toxicity in the beta cell. GlcN competes with glucose for GLUT2 and increases AMP/ATP ratio, which in turn activates AMPK. AMPK can inhibit cellular growth signaling. GLP-1 increases cAMP, which in turn leads to the recovery of glucose uptake through PKA-independent mechanisms that have yet to be elucidated.

(Fig. 8). This conclusion is supported by the findings that alternative energy supplementation using methyl pyruvate alleviated the glucosamine-induced deterioration of cell survival [13]. The mechanism by which glucosamine inhibits glucose uptake may originate from certain glycosylated proteins made through HBP, as seen in extrapancreatic tissues. However, at least in beta cells, glycosylated proteins appeared not to be primarily involved in the effect of glucosamine, because neither BADGE nor tunicamycin hindered the effect of glucosamine. Furthermore, treatment with PUGNAc for $48 \mathrm{~h}$ at a concentration high enough to nourish intracellular glycosylated proteins did not exert a significant inhibition of beta-cell survival. These results suggest that glucosamine may have another pathway for its negative effect on beta-cell survival, such as through the competition of glucosamine with glucose for GLUT2, which would diminish the entry of glucose into the beta cells [17]. In addition, it may be worth pointing out that, with time dependency, intracellular glucosamine might affect the glucose uptake of beta cells through an allosteric inhibition of GlcN-6-P for glucokinase [26] or a glucosamine-induced increase in reactive oxygen species [27]. In this regard, it may be ineffective to employ acute treatment with glucosamine in beta cells for the purpose of mimicking glucotoxicity. Rather, glucosamine may be acutely used in beta cells to mimic a glucose-depletion status, such as hypoglycemia or metabolic inhibition, which could activate the AMPK signaling pathway.

Beta-cell growth signals have been known to be inhibited by AMPK activation associated with energy depletion [28]. Consistent with this observation, glucosamine increased AMPK activity and decreased the phosphorylation of P70S6K and S6RP. Of particular interest, the phosphorylation of Akt was shown not to decrease; rather, it increased during the early period of glucosamine exposure. This change may act as negative feedback that follows the inhibition of other growth signals by glucosamine, as seen with other chemicals in certain cancer cells [29] as well as in beta cells [30]. In contrast, decreased Akt phosphorylation observed $48 \mathrm{~h}$ after glucosamine exposure might offer evidence for its eventual participation in the cellular apoptotic process, since the total amount of Akt was not decreased at that time.

The protective effect of GLP-1 was the amelioration of the decreased glucose uptake of beta cells caused by glucosamine, according to the cell viability assay, which was comparable to the effect of methyl pyruvate. This suggests that GLP-1 may lead to recovery of the ATP/ AMP ratio. This was shown to occur via cAMP-dependent mechanisms, probably through its G-protein-coupled receptors and adenylate cyclase activation [31]. Betacell GLP-1 has been shown to be important for facilitating ATP production in response to administered glucose by increasing mitochondrial glucose metabolism [31]. In addition, the expression of glucokinase and GLUT2 were shown to be increased by GLP-1-mediated signaling [3234].

GLP-1 can also transactivate EGFR in the beta-cell membrane. Subsequently, it activates PI3-kinase to facilitate cell growth and proliferation [35]. It is unlikely that this pathway is involved in the effect of GLP-1 on alleviating impaired glucose uptake by glucosamine, as it was demonstrated to occur even in the presence of LY294002. It is interesting that GLP-1 exhibits different mechanisms for beta-cell protection from glucosamine toxicity and glucolipotoxicity, in which GLP-1 was noted to exert its effect preferentially through the PI-3 kinase/ Akt pathway [35]. This also suggests that glucotoxicity and glucosamine toxicity in beta cells may have different mechanisms, at least during the early period of exposure. Hyperglycemia in type 2 diabetes was shown to induce gradual loss of beta-cell insulin, glucokinase and GLUT2 expression, resulting in the further deterioration of insulin secretory capacity [36]. This impairment may be ameliorated by the mechanism of GLP-1 which is shown in the present study.

Kim/Park/Park/Lim/Baek/Suh/Lim/Ryu/Song 


\section{Acknowledgements}

This work was supported by grant No (R13-2002028-03002-0) from the Basic Research Program of
KOSEF and in part by a research grant from the Investigator Initiated Studies Program of Merck. The opinions expressed in this paper are those of the authors and do not necessarily represent those of Merck.

\section{References}

Hathcock JN, Shao A: Risk assessment for glucosamine and chondroitin sulfate. Regul Toxicol Pharmacol 2007;47:7883.

${ }_{2}$ Oh HJ, Lee JS, Song DK, Shin DH, Jang BC, Suh SI, Park JW, Suh MH, Baek WK: D-glucosamine inhibits proliferation of human cancer cells through inhibition of p70S6K. Biochem Biophys Res Commun 2007;360:840-845.

-3 Cooksey RC, Hebert LF, Jr., Zhu JH, Wofford P, Garvey WT, McClain DA: Mechanism of hexosamine-induced insulin resistance in transgenic mice overexpressing glutamine:fructose-6phosphate amidotransferase: decreased glucose transporter GLUT4 translocation and reversal by treatment with thiazolidinedione. Endocrinology 1999;140:1151-1157.

-4 Patti ME, Virkamaki A, Landaker EJ, Kahn CR, Yki-Jarvinen H: Activation of the hexosamine pathway by glucosamine in vivo induces insulin resistance of early postreceptor insulin signaling events in skeletal muscle. Diabetes 1999;48:15621571

5 Anello M, Spampinato D, Piro S, Purrello F, Rabuazzo AM: Glucosamineinduced alterations of mitochondrial function in pancreatic beta-cells: possible role of protein glycosylation. Am J Physiol Endocrinol Metab 2004;287:E602-E608.

-6 D'Alessandris C, Andreozzi F, Federici M, Cardellini M, Brunetti A, Ranalli M, Del Guerra S, Lauro D, Del Prato S, Marchetti P, Lauro R, Sesti G: Increased O-glycosylation of insulin signaling proteins results in their impaired activation and enhanced susceptibility to apoptosis in pancreatic beta-cells. FASEB J 2004;18:959-961.
Buse MG: Hexosamines, insulin resistance, and the complications of diabetes: current status. Am J Physiol Endocrinol Metab 2006;290:E1-E8. Baron AD, Zhu JS, Zhu JH, Weldon H, Maianu L, Garvey WT: Glucosamine induces insulin resistance in vivo by affecting GLUT 4 translocation in skeletal muscle. Implications for glucose toxicity. J Clin Invest 1995;96:27922801

Giaccari A, Morviducci L, Zorretta D, Sbraccia P, Leonetti F, Caiola S, 16 Buongiorno A, Bonadonna RC, Tamburrano G: In vivo effects of glucosamine on insulin secretion and insulin sensitivity in the rat: possible relevance to the maladaptive responses to chronic hyperglycaemia. Diabetologia 1995;38:518-524.

Rossetti L, Hawkins M, Chen W, Gindi J, Barzilai N: In vivo glucosamine infusion induces insulin resistance in normoglycemic but not in hyperglycemic conscious rats. J Clin Invest 1995;96:132-140.

Gao Y, Parker GJ, Hart GW: Streptozotocin-induced beta-cell death is independent of its inhibition of $\mathrm{O}$ GlcNAcase in pancreatic Min6 cells. Arch Biochem Biophys 2000;383:296302.

Han DH, Chen MM, Holloszy JO Glucosamine and glucose induce insulin resistance by different mechanisms in rat skeletal muscle. Am J Physiol Endocrinol Metab 2003;285:E1267-E1272.

Hresko RC, Heimberg H, Chi MM, Mueckler M: Glucosamine-induced insulin resistance in 3T3-L1 adipocytes is caused by depletion of intracellular ATP. J Biol Chem 1998;273:20658-20668. (eidigh JL, Cooksey RC, McClain DA: Transgenic mice with increased hexosamine flux specifically targeted to beta-cells exhibit hyperinsulinemia and peripheral insulin resistance. Diabetes 2000;49:1492-1499.

15 Liu K, Paterson AJ, Chin E, Kudlow JE: Glucose stimulates protein modification by O-linked GlcNAc in pancreatic beta cells: linkage of O-linked GlcNAc to beta cell death. Proc Natl Acad Sci U S A 2000;97:2820-2825.

McClain DA: Hexosamines as mediators of nutrient sensing and regulation in diabetes. J Diabetes Complications 2002;16:72-80.

$>17$ Uldry M, Ibberson M, Hosokawa M, Thorens B: GLUT2 is a high affinity glucosamine transporter. FEBS Lett 2002:524:199-203.

18 Buteau J: GLP-1 receptor signaling: effects on pancreatic beta-cell proliferation and survival. Diabetes Metab 2008;34(Suppl 2):S73-77.

$>19$ Edgerton DS, Johnson KM, Neal DW, Scott M, Hobbs CH, Zhang X, Duttaroy A, Cherrington AD: Inhibition of dipeptidyl peptidase-4 by vildagliptin during glucagon-like Peptide 1 infusion increases liver glucose uptake in the conscious dog. Diabetes 2009;58:243249.

Lee YS, Shin S, Shigihara T, Hahm E, Liu MJ, Han J, Yoon JW, Jun HS: Glucagonlike peptide-1 gene therapy in obese diabetic mice results in long-term cure of diabetes by improving insulin sensitivity and reducing hepatic gluconeogenesis. Diabetes 2007;56:1671-1679. 
-21 Parlevliet ET, Schroder-van der Elst JP, Corssmit EP, Picha K, O’Neil K, Stojanovic-Susulic V, Ort T, Havekes LM, Romijn JA, Pijl H: CNTO736, a novel glucagon-like peptide-1 receptor agonist, ameliorates insulin resistance and inhibits very low-density lipoprotein production in high-fat-fed mice. J Pharmacol Exp Ther 2009;328:240-248.

22 Pospisilik JA, Stafford SG, Demuth HU, Brownsey R, Parkhouse W, Finegood DT, McIntosh $\mathrm{CH}$, Pederson RA: Long-term treatment with the dipeptidyl peptidase IV inhibitor P32/98 causes sustained improvements in glucose tolerance, insulin sensitivity, hyperinsulinemia, and beta-cell glucose responsiveness in VDF $(\mathrm{fa} / \mathrm{fa})$ Zucker rats. Diabetes 2002;51:943-950.

23 Sancho V, Nuche B, Arnes L, Cancelas J, Gonzalez N, Diaz-Miguel M, MartinDuce A, Valverde I, VillanuevaPenacarrillo ML: The action of GLP-1 and exendins upon glucose transport in normal human adipocytes, and on kinase activity as compared to morbidly obese patients. Int J Mol Med 2007;19:961966.

$\$ 24$ Arnes L, Gonzalez N, Tornero-Esteban P, Sancho V, Acitores A, Valverde I, Delgado E, Villanueva-Penacarrillo ML: Characteristics of GLP-1 and exendins action upon glucose transport and metabolism in type 2 diabetic rat skeletal muscle. Int J Mol Med 2008;22:127-132.
25 Jibb LA, Richards JG: AMP-activated protein kinase activity during metabolic rate depression in the hypoxic goldfish, Carassius auratus. J Exp Biol 2008;211:3111-3122.

26 Balkan B, Dunning BE: Glucosamine inhibits glucokinase in vitro and produces a glucose-specific impairment of in vivo insulin secretion in rats. Diabetes 1994;43:1173-1179.

27 Kaneto H, Xu G, Song KH, Suzuma K, Bonner-Weir S, Sharma A, Weir GC: Activation of the hexosamine pathway leads to deterioration of pancreatic betacell function through the induction of oxidative stress. J Biol Chem 2001;276:31099-31104.

$\checkmark 28$ Hardie DG: New roles for the LKB1 $\rightarrow$ AMPK pathway. Curr Opin Cell Biol 2005;17:167-173.

Mahalingam D, Sankhala K, Mita A, Giles FJ, Mita MM: Targeting the mTOR pathway using deforolimus in cancer therapy. Future Oncol 2009;5:291-303. Cai Y, Wang Q, Ling Z, Pipeleers D, McDermott P, Pende M, Heimberg H, Van de Casteele M: Akt activation protects pancreatic beta cells from AMPK-mediated death through stimulation of mTOR. Biochem Pharmacol 2008;75:1981-1993.
Kwon G, Marshall CA, Pappan KL, Remedi MS, McDaniel ML: Signaling elements involved in the metabolic regulation of mTOR by nutrients, incretins, and growth factors in islets. Diabetes 2004;53(Suppl 3):S225-232.

2 Lam NT, Kieffer TJ: The multifaceted potential of glucagon-like peptide-1 as a therapeutic agent. Minerva Endocrinol 2002;27:79-93.

33 Muraoka T, Murao K, Imachi H, Yu X, Li J, Wong NC, Ishida T: PREB regulates transcription of pancreatic glucokinase in response to glucose and cAMP. J Cell Mol Med DOI: 10. 1111/j.15824934.2008.00469.x.

-34 Holz IV GG, Kuhtreiber WM, Habener JF: Pancreatic beta-cells are rendered glucose-competent by the insulinotropic hormone glucagon-like peptide-1(7-37). Nature 1993;361:362-365.

Buteau J, El-Assaad W, Rhodes CJ, Rosenberg L, Joly E, Prentki M: Glucagon-like peptide-1 prevents beta cell glucolipotoxicity. Diabetologia 2004;47:806-815.

Jorns A, Tiedge M, Ziv E, Shafrir E, Lenzen S: Gradual loss of pancreatic betacell insulin, glucokinase and GLUT2 glucose transporter immunoreactivities during the time course of nutritionally induced type-2 diabetes in Psammomys obesus (sand rat). Virchows Arch 2002;440:63-69. 